\title{
쓰나미 재건복구지원 동향
}

\section{인도양 해일경보 / 경감시스템 개발을 위한 국제전문가회의 결과}

유네스코 정부간해양학위원회(IOC) 주최로 2005.3.3-8간 유네스코 본부에서 표제 회의가 개최된 바, 주요 내용은 아래와 같음. (우리나라에서는 주불한국대사관 최은옥서기관, 한국전자통신연구원 이광 순 선임연구원 참석)

\section{1. 핵심 내용}

- 2004.12.26 인도양의 해일 대참사 이후, 지진과 해일의 영향에 관한 아세안지도자 특별회의 (2005.1.6, 자카르타), 재난감축을 위한 국제회의 (2005.1.18-22, 일본 고베), 해일 조기경보체제 구축을 위한 장관급 회의(2005.1. 28-29, 태국 푸켓) 등이 개최된 데 이어,

- 표제회의는 유네스코 국제해양학위원회(IOC)가 중심이 되어 인도양지역 해일 경보시스템 구축

을 추진하기로 함에 따라 개최된 첫 전문가 회의임

- 이 회의를 통해 인도양 국가들의 해일 경보/경감 시스템의 기술적 측면에 대한 인식을 제고하고, ‘인도양 해일 경보/경감 시스템' 의 설계 · 실행계획 수립 및 추진일정을 마련하고자 함

- 다음과 같이 '인도양 해일 경보/경감 시스템'을 구축하는 방안을 마련하였으며, 동 방안은 금년 4월 의 2 차 전문가회의와 6 월의 $\mathrm{IOC}$ 총회를 통해 확정될 예정

- 시스템 구축 전단계에서는, 태평양 해일 경보 · 경감시스템을 활용하여 인도양 지역에 정보를 제공하고, - 2006년까지 인도양 지역 전체를 측정계와 해저센서로 연결하는 지역경보 센터를 설립하는 등 해 일경보시스템을 구축함 


\section{2. 회의 주요 내용}

\section{가. Matsuura 사무총장(개회사)}

- 각 국 해일 경보센터로 활동할 national agency 지정 등을 통한 협력망 구축과 해일 위험 측정을 위한 연구의 협력체계 구축이 필요하다고 하며,

· 인도양 해일 경보시스템은 세계 해일 경보시스템 구축의 첫단계이며, 지속가능개발 세계정상회의 (WSSD, 2002)의 촉구로 향후 10년내 구축 예정인 세계 지구관측시스템(GEOSS, Global Earth Observation System of Systems)과도 연계될 수 있는 강점이 있음을 강조함

\section{나. 주요 발표내용 및 논의}

· 인도양지역 해일경보시스템 구축을 위한 기본계획 마련을 위해 1)기술적 측면, 2)운영조직, 3)인식 제고 및 교육훈련의 3 개 주제로 나누어 관련 국제기구 및 지역 · 국가센터 등에서 그간의 축적된 기 술을 소개하고 인도양 해일경보 시스템 구축에 고려하여야 할 사항을 논의하였음

· 기술적 측면에서는 지진 및 해수면 변화 등 위험요인 탐지, 위험정도의 평가 및 분석, 위험경고메시 지 전파 등에 대한 논의가 이루어졌음

- 우리나라는 위험경고메시지 전파와 관련하여 최신 IT 기술의 활용을 검토하는 것이 필요하다고 언급하며, 새롭게 개발한 T-DMB(Territorial-Digital Multimedia Broadcasting) 방식을 소개 하였음

· 운영조직 측면에서는 각 국의 시스템과 지역시스템 및 전세계시스템 연계의 중요성과 관련정보 상 호교환의 중요성이 강조되었음

· 인식제고 및 교육훈련에 관하여는 세계시스템 또는 지역시스템을 구축하더라도 결국은 각국에서 활용하는 것이 중요하므로 각 국의 자국민에 대한 전파시스템 구축 및 교육훈련 등이 강조되었음

\section{다. 주요 추진 방안(안) 권고}

· IOC 총회에서 인도양 해일 경보 및 경감시스템을 위하여 인도양 지역 국가들로 구성된 정부간 조정 기구(ICG/IOTWS)를 구성 (타지역 국가는 옵저버로 참여)

- IOC 사무국이 ICG/IOTWS의 사무국을 겸함

· 각 회원국은 자국 영토내 경보발령을 통제할 책임이 있으며, 자국민에게 해일의 위험성을 홍보하고 교육·훈련함으로서 해일 경보발령시 행동요령을 전파함. 이를 위하여 국내 해일경보센터 설립하 고 focal point를 지정

· 측정시스템, 위험관리, 경보(전파)시스템을 기술적인 측면을 다루기 위한 임시 워킹그룹을 구성하도 
록 IOC 사무국에 권고하고, 그 추진 경과를 4 월 2차 회의시 보고하도록 함

- 임시조치로, 태평양해일경보센터(PTWC)와 일본기상청(JMA)에서 인도양지역 국가들에 해일 정보 를 제공

- 각 인도양지역 국가는 2005.4.1까지 이 정보를 받을 곳을 정하여 등록함

· 각국 해일재난 경감 프로그램은 정부, 민간부문 및 시민사회단체간의 협력이 중요

\section{3. 향후 일정}

· 제2차 전문가 회의(2005.4.14-16, 모리셔스 Port Louis)에서 추가 논의

· 2005.6.21-30 IOC 총회(유네스코 본부)에서 확정

\section{4. 관찰 및 평가}

· 표제회의는 인도양 지역 국가들에게 인도양 해일경보시스템 구축에 필요한 기술적 측면에 대한 인 식을 높이고 효율적인 시스템 구축안을 마련하기 위한 첫 전문가 회의로,

- 국제해양학위원회(IOC)의 세계해일경보체제협의체(ITSU)를 중심으로 국제해일 정보센터(ITSC), 세계기상기구(WMO), 세계해양기구(IMO), 세계지진기구(GSN) 등 관련 국제기구와 각 국 기상 청, 기상연구센터 등의 전문가들이 그간의 축적된 기술을 소개하고, 인도양시스템 구축에 고려해 야할 제반 사항을 논의하였음

· 금번 회의 소요비용은 일본에서 제공하였으며, 그간 해일경보시스템을 구축·운영하고 있는 태평양 지역의 축적된 기술과 노하우를 인도양시스템 구축에 활용하고, 시스템구축 전의 임시단계에서는 태평양경보시스템에서 인도양 지역에도 정보를 제공하기로 함에 따라, 태평양해일경보시스템 구 축·운영에 중심적인 역할을 하고 있는 미국과 일본이 많은 역할을 하고 있음

· 금번 회의를 통해 인도양 해일경보시스템 구축에 대한 개괄적인 계획(안)은 마련하였으나, 소요비용 의 추산 및 조달 방안은 검토되지 않았으며, IOC 사무국측은 이를 위한 각국의 지원을 요청하고 있음 - 우리나라는 금번 회의에서 위험경고 메시지 전파와 관련하여 활용될 수 있는 T-DMB(TerritorialDigital Multimedia Broadcasting) 기술을 소개하였음. 국제해양학위원회(IOC)이사국이며, 세계 해일경보체제협의체(ITSU) 회원국으로서, 향후의 인도양 해일경보시스템 구축 추진과정에도 IT 분 야 신기술 전문가 뿐만아니라 해일 관련 분야 관계관 및 전문가의 지속적 참여가 요망됨 


\section{스페인의 남아시아 해일관련 지원활동 설명회}

스페인 외교부는 1.25(화) Salarich 아태국장 주재로 아태지역 대사관 관계자를 초청, 남아시아 해일 관련 주재국 정부의 지원활동 설명회를 개최한 바, 주요 내용은 아래와 같음

\section{1. 스페인 정부의 지원현황}

· 외교부, 산업통상관광부, 내무부, 국방부, 지방자치단체등이 총 6810 만 유로 상당의 지원을 실시 또는 추진중

\section{2. 스페인 외교부의 지원활동}

· 스페인 외교부 산하 국제협력처(ACEI)는 현재까지 420만 유로 상당 지원

- 5회에 걸친 구호품 수송(100만 유로 상당)

- 피해지역에서 활동중인 스페인 NGO 들의 Emergency Plan 자금 지원(200만 유로) 약속

- UN기관(UNHCR, UNICEF 등)을 통한 자금지원(100만 유로) 약속

- 추가 구호품 수송(20만 유로) 예정

\section{3. 스페인 외교장관의 피해지역 방문 및 추가지원}

- Moratinos 외교장관은 지난주 스리랑카, 태국, 인도네시아를 방문, 현지 당국 책임자들과 만나 피해복구 및 지원 협력 방안에 관해 논의

- 태국 방문시, 피해복구 재건 신속화, 관광객 신뢰 증대를 위해 세계관광기구 집행위를 해일 피 해지역에서 개최하는 방안 협의

· 상기 3 개국 방문시 510 만 유로의 추가지원 결정

- 스리랑카, 인도네시아에서 활동중인 스페인 NGO들의 Emergency Plan 및 신규 복구 프로젝 트 지원(3백만 유로)

- 인도적 목적 국제기구 지원(2백만 유로)

- 피해지역 수산, 공예, 관광, 소규모 금융지원 사업발굴 지원(10만 유로) 


\section{4. 기타 공공기관의 지원활동}

\section{가. 정부기관}

- 산업통상관광부 5 천만 유로, 내무부 2 만 유로(검시관 4 명 태국 파견), 국방부에서 780 만 유로 규모지원 예정

\section{나. 지방자치단체}

·각 주정부에서 200만 유로 지원

\section{5. 향후 계획}

· 금번 설명회에서 Salarich 아태국장은 금년 여름 이전 Zapatero 총리가 피해국가를 방문할 계 획을 갖고 있으며, 이를 위해 2월초반경 아태지역 대사들을 초청하여 피해국가지원에 대한 의견 교환, 스페인이 준비중인 대아시아정책(Action plan for Asia-Pacific)의 priority 재검토에 대 해 논의할 예정이라고 밝힘 


\section{인도네시아 재건복구사업관련 공여국 동향}

\section{1. 인도네시아 재건복구지원}

재건복구지원의 일환으로 World Bank에 의해 주도되고 있는 다자간신탁기금에 의한 지원방식에 대해 공여국들이 의견을 교환하는 비공식 회의가 2005. 2. 17(목) 자카르타소재 World Bank 사 무소에서 개최되었음. 이와 관련 공여국들의 동향은 아래와 같음

\section{2. 공여국 동향}

- 일본, 미국, 독일 등 주요 공여국들은 양자간사업을 위주로 지원하되 부분적으로 다자간사업 참 여도 고려할 수 있다는 정도로 의사를 표명함. 특히 일본은 다자간신탁기금의 문제점을 강하게 지적하였음

· 유럽국가 중 소액 공여국과 $\mathrm{EU}$ 등은 일단 다자간신탁기금 방식을 긍정적으로 평가하고 참여할 의사가 있음을 간접 표명함

· $\mathrm{ADB}, \mathrm{UNDP}$ 등은 과거 경험상 다자간 재원조달에 의한 공동사업이 기금모금 등 여러 측면에서 용이하지 않은 면도 있었음을 지적함

- 각 공여국 및 국제기구 등 공히 다자간신탁기금 방식에서 예상되는 문제들을 활발하게 발표함.

- 재원사용의 투명성에 대한 보장 필요(Accountability, Auditing)

- 공여국별로 약속한 기금의 실제 지원이 지연되면 사업추진 자체가 지연 가능

- 사업추진 관련 시스템, 법제도, 관행 등이 서로 다르고 재건, 건설의 표준이 서로 다른 공여국 간의 조화, 조정이 필요하며 Sector별 조정, 양자간/다자간 조정도 필요함. 또한, 아프간 및 이라크 재건사업과는 달리 인니의 경우 자체 시스템을 상당히 존중할 필요

- 다자간신탁기금이 보다 효과적으로 쓰이려면 BAPPENAS 주도로 이루어지고 있는 청사진 작 성단계에 기금 공여국들의 적극 참여 필요 


\section{스리랑카 재건복구사업 동향}

\section{1. 주요동향}

\section{가. 대통령 재건사업 착수시기 발표}

- Kumaratunga 대통령은 오는 3.1(화)부터 지진해일 피해지역에 대한 재건사업에 착수할 예정이 며, 이를 위해 외국 정부, 지방 및 국제기구와 각각 양해각서(MOU)를 체결할 것이라고 발표함.

- Kumaratunga 대통령은 주의회 및 지방의회를 포함한 사회 각 분야의 참여를 확보하기 위한 사업 추진체제를 적절한 절차를 거쳐 발표할 것이라고 언급하고 피해지역의 인프라 재건에 17 억 불, 주택재건에 3억불이 소요될 것으로 추정된다고 말함

- Mahinda Rajapakse 수상도 지진해일 피해로 약 10 만채의 가옥을 새로 건축해야 할 것이라고 언 급하고 이제는 긴급 구조단계를 지나 국가재건을 위해 필요한 조치를 취해야 할 단계라고 말함

\section{나. 외국 정부 및 국제기구의 재건사업 참여동향}

\section{(1) 세계은행 국제개발협회(IDA)}

- IDA는 스리랑카 정부와 공동으로 북 · 동부지역의 주택 재건사업에 4 년에 걸쳐 75 백만불을 지원 하여 4만 6천채의 주택을 건설키로 함(동 사업의 총 소요액 77 백만불중 2 백만불만 스리랑카 정 부가 부담)

· 동 사업에는 주택건설 뿐만 아니라 민간인의 토지소유권 회복, 건설노동 인력훈련, 토지분쟁 해 결, 사회 및 환경영향 평가, 민간사업 기술검사, 정보관리시스템 등의 사업도 포함될 것임

· 동 사업의 시행을 위한 사업팀이 북·동부지역 8 개 구역에 설치될 예정이며 북·동부 주의회내 에 설치될 “북·동부 주택재건 사업단”이 각 사업팀을 관장하게 될 것임

\section{(2) 이태리정부}

- 이태리정부는 지진해일 피해를 입은 4 개 구역내 19 개 학교의 재건사업을 지원하기로 함 $(2.15$ $\mathrm{MOU}$ 체결)

- 지원 대상 학교 : Batticaloa 2개교, Trincomalee 8개교, Ampara 4개교, Galle 5개교

- 사업내용 : 교실 이외에 컴퓨터학습센터, 실험실, 예체능실, 도서관, 운동장, 교직원실 등

- 지원내용 : 전문가팀 파견, 자재 및 장비, 학습용 기자재 지원 등 
- 구체적인 실행계획은 전문가팀에 의해 수립될 것이며 6개월 내에 계획수립이 완료될 예정

· 이태리정부는 상기 학교재건사업 이외에 수산분야, 북동부 및 남부지역 재건사업 지원을 위해서 도 MOU를 체결한 바 있으며, 지진해일 피해 국가에 대한 이태리정부의 총 지원 약속액 150 백만 유로중 80 90\%가 스리랑카에 지원될 것으로 알려짐

\section{다. Galle시 종합확장계획 발표}

· 남부지역 중심도시로서 지진해일 피해가 심한 Galle시의 종합확장계획이 2.14(월) 발표됨

계획요지

- 신시가지 경계의 확대

- $100 \mathrm{~m}$ 완충구역 규정의 엄격한 적용

- Galle 역 및 버스정류장 이전

- Mattegada 50에이커 부지에 Galle 스포츠 단지 신규 조성 및 인근 최초 의 민간 공항 조성

- Gintota강 유역을 주변의 관련시설을 포괄하는 '학습회랑'으로 조성

- 과거 화란 감옥건물을 세계 최초의 감옥호텔로 개장

- 쇼핑센터를 Galle 도심에서 $200 \mathrm{~m}$ 내부로 이전 조성

- Unawatuna를 남부주 관광센터로 전환

- Galle항을 국제 요트 계류장으로 개선

- 금번 확장계획은 Galle시를 제2의 상업 및 행정중심지로 조성한다는 개념에 기초를 두어 수립한 것으로 알려짐 